\title{
VEIKSNIAI, TURINTYS IৃTAKOS KAUNO GYVENTOJŲ PASIRINKIMUI AKTYVIAI LEISTI LAISVALAIKİ LAUKO TRENIRUOKLIŲ AIKŠTELĖSE
}

\author{
Giedrè Gudaitytė, Irena Valantinè \\ Lietuvos sporto universitetas, Kaunas, Lietuva
}

\begin{abstract}
ANOTACIJA
Straipsnyje pristatomi veiksniai, turintys įtakos Kauno gyventojų pasirinkimui laisvalaikị leisti lauko treniruoklių aikštelèse. Ivertinus gyventojų požiūri galima teigti, kad sportavimas gryname ore lauko treniruoklių aikštelèse yra patraukli aktyvaus laisvalaikio forma. Manoma, kad vieni svarbiausių veiksnių, skatinančiu naudotis lauko treniruokliais, yra galimybė gauti nemokamą paslaugą, rami aplinka, lauko treniruoklių ivvairovė, tinkamas geografinis lauko treniruoklių aikštelių išsidėstymas. Pasirinkimą sportuoti gryname ore lauko treniruoklių aikštelèse lemia ir tam tikri naudingumo faktoriai: galimybè aktyviai praleisti laisvalaiki gamtoje, pagerinti miego kokybę, rasti draugų ir bendraminčių, ugdyti valią ir ištvermę, atgauti energija, sumažinti įtampą, patobulinti kūno formas.
\end{abstract}

Raktažodžiai: aktyvus laisvalaikis, lauko treniruokliai, miesto parkai.

\section{IVADAS}

Tyrimo aktualumas. Pastaruoju metu pasaulio sveikatos specialistai ir mokslininkai vis daugiau dėmesio skiria aktyvaus laisvalaikio problemoms, tačiau dažnai jų nuomonès šiuo klausimu nesutampa. Sveikatos specialistų nuomone, ši sritis išnagrinèta jau gana išsamiai ir aktyvus laisvalaikis pripažintas kaip tinkamas būdas fizinio pasyvumo problemoms spręsti. Mokslininkų (Rosenberger, Bergerson, Kline, 2009; Godbey, Mowen, 2010 ir kt.) teigimu, aktyvaus laisvalaikio ir jo ittakos žmogui klausimai turi būti ir toliau plačiai analizuojami.

C. Walker (2004), J. J. Pigram, J. M. Jenkins (2006) teigia, kad, siekiant sumažinti fizinio pasyvumo didejjimo grèsmę, apie kurią perspèja sveikatos specialistai, būtina atsižvelgti i visuomenės poreikius. Remiantis mokslininkų (Godbey, Mowen, 2010; Horká, Hromádka, 2010; Peters, 2010 ir kt.) atliktais gyventojų nuomonès tyrimais, vienas iš veiksmingiausių šios problemos sprendimu yra modernizuoti viešąsias erdves, pavyzdžiui, miesto parkus, paversti jas aktyvaus laisvalaikio zonomis. A. C. Deborah ir kt. (2007) teigia, kad miesto parkai yra puiki vieta žmonėms, pasirinkusiems aktyvią gyvensena, nes daugelis yra puikiai pritaikyti sportuoti, užsiimti kita fizine veikla. R. S. Rosenberger, R. T. Bergerson, J. D. Kline (2009) teigia, kad viena tinkamiausių priemonių skatinti aktyvų laisvalaiki yra sporto infrastruktūros miestų parkuose kūrimas ir atnaujinimas. Nors plačiai diskutuojama apie lauko sporto aikštelių reikalingumą viešosiose erdvėse, tyrimų, atskleidžiančių veiksnius, turinčius įtakos jų pasirinkimui, dar nepakanka. Vis dėlto spartus miestų parkų modernizavimas ir naujų aktyvaus laisvalaikio zonų juose kūrimas patvirtina gyventojų poreikį laisvalaikį leisti fiziškai aktyviai.

Tyrimo objektas - veiksniai, turintys ittakos lauko treniruoklių pasirinkimui laisvalaikiu.

Tyrimo tikslas - nustatyti veiksnius, turinčius įtakos Kauno gyventojų pasirinkimui laisvalaikị leisti lauko treniruoklių aikštelèse. 


\section{Tyrimo uždaviniai:}

1. Ištirti naudojimosi lauko treniruokliais galimybes.

2. Nustatyti veiksnius, lemiančius Kauno gyventojų pasirinkimą sportuoti gryname ore lauko treniruoklių aikštelèse.

Tyrimo metodai: mokslinės literatūros analizè, anketinė apklausa, aprašomoji statistika.

\section{TEORINIS PAGRINDIMAS}

Aktyvus laisvalaikis gamtoje, sveikatos stiprinimas, rūpinimasis savo kūnu, geresnès gyvenimo kokybės siekis yra pagrindinès priežastys, skatinančios aktyvaus laisvalaikio gamtoje sektoriaus plètrą.

Aktyvų laisvalaikị sudėtinga apibrèžti glaustai ir visapusiškai, nes ši sąvoka vartojama skirtinguose kontekstuose. Tiek Lietuvos (Jankauskienė, 2008; Vitkienè, 2008), tiek užsienio autoriai (Horká, Hromádka, 2010; Bell et al., 2007; Tekin, 2004) aktyvaus laisvalaikio sąvoką apibrèžia kaip turinčią daug reikšmių.

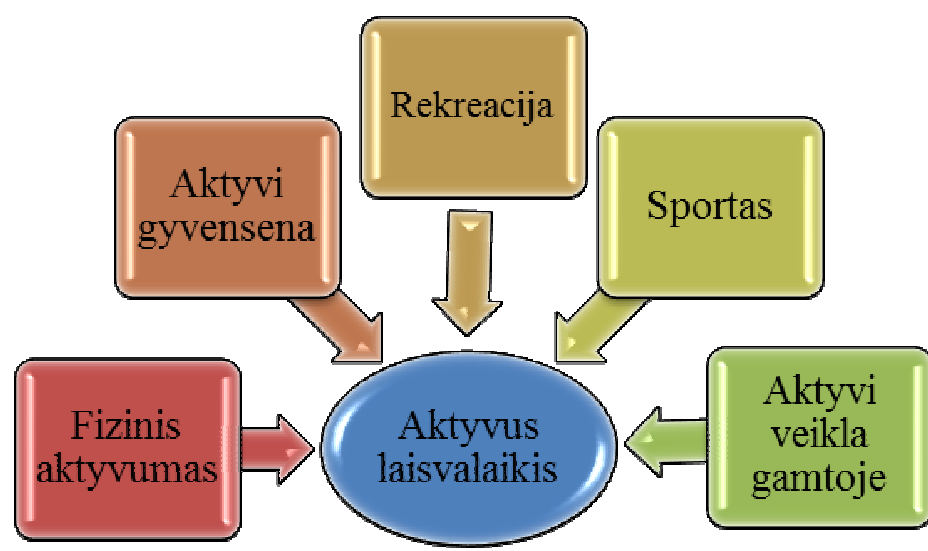

1 pav. Aktyvaus laisvalaikio sąvokos reikšmès

(sudaryta pagal: Horká, Hromádka, 2010; Jankauskienė, 2008; Vitkienè, 2008; Bell et al., 2007; Tekin, 2004)

H. Horká, Z. Hromádka (2010) aktyvų laisvalaiki apibrèžia kaip visapusišką fizinę veiklą, padedančią žmogui gerai jaustis. Anot A. Tekin (2004), aktyvus laisvalaikis siejamas su sportavimu, kai patiriamas malonumas, išliejama susikaupusi energija. Todèl daugelis veiklu, priskiriamų sportavimui, apibrěžiamos kaip aktyvaus laisvalaikio ir poilsio kategorijos. Pasak R. Jankauskienès (2008), kalbant apie fizini aktyvumą dažnai vartojami terminai „kūno kultūra“, „sportas visiems“, „sportas“. Dažnai jie siejami ir su aktyvaus laisvalaikio, mankštinimosi sąvokomis, tačiau negali būti vartojami kaip sinonimai, nes jų reikšmė skirtinga. Aktyvus laisvalaikis siejamas ir su rekreacija. E. Vitkienè (2008) rekreaciją apibūdina kaip žmogaus sveikatos atgavimą, fizinių jègų atkūrimą, teigiamos emocinès, dvasinès, kultūrinès psichoemocinès būsenos, malonių pojūčių išgyvenimo atkūrimo ir atnaujinimo procesą.

S. Bell ir kt. (2007) aktyvų laisvalaiki priskiria prie veiklos gamtoje (angl. outdoor recreation). Remiantis S. Bell ir kt. (2007) atliktais tyrimais, laisvalaikio veikla gamtoje gali būti ir labai pasyvi (sėdèjimas, dvasinis poilsis, atsipalaidavimas, grožèjimasis vaizdais), ir labai aktyvi 
(slidinèjimas, jodinèjimas, važinëjimas dviračiu, sportavimas gryname ore). Vietos, puikiai tinkamos aktyviam poilsiui gamtoje, yra miškai, ežerų ir upių pakrantès, kalnai, miestų parkai ir kt.

Analizuodamas aktyvaus laisvalaikio praleidimo galimybes miestu parkuose, H. Frumkin (2003) nurodo ivairias galimybes naudotis aktyvaus laisvalaikio paslaugomis, tokiomis kaip sveikatingumo ir dviračių takai, vaikų žaidimų aikštelès, lauko treniruoklių aikštelès, kitos prasmingo poilsio zonos.

Remiantis A. C. Deborah ir kt. (2007) atliktais miestų viešujų erdvių patrauklumo tyrimais, miesto parkai yra ypač tinkamos vietos skatinti gyventojų fizini aktyvumą laisvalaikiu, nes šiuo metu parku infrastruktūra pritaikyta ir pasyviam, ir aktyviam poilsiui. Daugelyje užsienio parkų (pavyzdžiui, Kowloon Walled City Park (Honkonge), Hampstead Heath (Londone) ir t. t.) yra irengtos sporto aikštelès su specialiais įrenginiais, skirtais įvairiai fizinei veiklai.

Lietuvos miestu parkai taip pat keičia savo infrastruktūrą. Didejjant visuomenès aktyvios gyvensenos poreikiui, juose irengiama vis daugiau aktyvaus laisvalaikio zonų su moderniomis sporto aikštelèmis. Panašiai pertvarkomi ir Kauno miesto parkai - aktyvaus laisvalaikio mėgèjams jau įrengta daug dviračių takų, sporto ir žaidimų aikštelių. 1 lentelèje pateikiama lauko treniruoklių aikštelių Kauno miesto seniūnijose skirstinys, irengimo vieta ir treniruoklių skaičius.

1 lentelè. Lauko treniruoklių aikštelių Kauno miesto seniūnijose skirstinys, įrengimo vieta, treniruoklių skaičius (Kauno miesto savivaldybės visuomenės sveikatos rèmimo specialioji programa „Suaugusiujų ir vaikų fizinio aktyvumo skatinimas 2013“)

\begin{tabular}{|c|c|c|}
\hline Seniūnija & Treniruokliu aikštelès įrengimo vieta & Treniruoklių skaičius \\
\hline Aleksoto seniūnija & $\begin{array}{l}\text { Antakalnio parkas } \\
\text { Naugardiškių parkas }\end{array}$ & $\begin{array}{l}8 \\
5\end{array}$ \\
\hline Centro seniūnija & $\begin{array}{l}\text { Santakos parkas } \\
\text { Nemuno sala }\end{array}$ & $\begin{array}{c}7 \\
13\end{array}$ \\
\hline Dainavos seniūnija & Draugystès parkas & 13 \\
\hline Eigulių seniūnija & $\begin{array}{l}\text { Kalniečių parkas } \\
\text { Ašigalio g. } 28\end{array}$ & $\begin{array}{l}13 \\
13\end{array}$ \\
\hline Gričiupio seniūnija & Kovo 11-osios parkas & 13 \\
\hline Panemunès seniūnija & Panemunès paplūdimys & 13 \\
\hline Petrašiūnų seniūnija & $\begin{array}{l}\text { Masiulio g. } 17 \\
\text { Kauno marių pirmasis paplūdimys }\end{array}$ & $\begin{array}{l}13 \\
13\end{array}$ \\
\hline Šančių seniūnija & $\begin{array}{l}\text { Aukštujų Šančių skveras } \\
\text { Žemieji Šančiai, prie dviračių tako }\end{array}$ & $\begin{array}{l}7 \\
6\end{array}$ \\
\hline Šilainių seniūnija & $\begin{array}{l}\text { Santarvès parkas } \\
\text { Kuršiu g. }\end{array}$ & $\begin{array}{l}13 \\
13\end{array}$ \\
\hline Vilijampolès seniūnija & $\begin{array}{l}\text { Sajungos aikštė } \\
\text { Lampédžiai }\end{array}$ & $\begin{array}{l}13 \\
13\end{array}$ \\
\hline
\end{tabular}

Iš 1 lentelès matyti, kad daugiausia treniruoklių (po 26) įtaisyta Eigulių, Petrašiūnu̧, Šilainių ir Vilijampolès seniūnijose, kur šiuo metu irengta po dvi lauko treniruokliu aikšteles. Su mažiau lauko treniruoklių, bet taip pat po dvi aikšteles irengta ir Aleksoto (13 treniruokliu), Centro (20) bei Šančių (13) seniūnijose. Dainavos, Gričiupo ir Panemunès seniūnijose irengta po vieną tokią aikštelę, jose ịtaisyta po 13 lauko treniruoklių.

Išanalizavus Kauno miesto savivaldybès visuomenès sveikatos rèmimo specialiają programą „Suaugusiuju ir vaikų fizinio aktyvumo skatinimas 2013“ matyti, kad Kauno lauko treniruokliu aikštelès irrengtos gana patogiose gyventojams vietose, tačiau jų dar nepakanka. Ši paslauga sulaukè 
didžiulio gyventojų susidomėjimo, todèl numatyta 2014 m. programą tęsti ir kiekvienoje seniūnijoje irengti dar daugiau lauko treniruoklių aikštelių.

Apibendrinant galima teigti, kad viešieji miestų parkai yra ypač tinkamos vietos laisvalaikiui praleisti. Skatinant gyventojų fizini aktyvuma, populiarinant aktyvų laisvalaikį, didelis dèmesys skiriamas miesto parkų infrastruktūros pertvarkymui, naujų lauko poilsio zonų kūrimui. Parkuose irengiama vis daugiau aktyvaus poilsio zonų, kur gyventojai gali naudotis įvairiomis aktyvaus laisvalaikio paslaugomis, tarp jų - ir lauko treniruokliais. Kiekvienais metais lauko treniruokliu poreikis dideja, todèl galima daryti prielaida, kad šios paslaugos plètra lemia pasyvių gyventojų skaičiaus mažèjimą, skatina socialinę integraciją, racionalų parkų išteklių naudojimą, suteikia puikią galimybę aktyviai leisti laisvalaiki gryname ore ištisus metus.

\section{TYRIMO METODAI IR ORGANIZAVIMAS}

Siekiant nustatyti veiksnius, turinčius įtakos Kauno gyventojų pasirinkimui laisvalaiki leisti lauko treniruoklių aikštelèse, buvo atliktas kiekybinis tyrimas. Tyrimas vyko $2013 \mathrm{~m}$. kovo 1-31 d. Jame dalyvavo 369 respondentai, iš jų 269 moterys (73 proc.) ir 100 vyrų (27 proc.). Respondentu amžius - nuo 18 iki 62 metų. 219 respondentų buvo apklausta tiesiogiai, dalyvaujant tyrèjui, 150 respondentu - internetu.

Duomenys surinkti anketinès apklausos metodu. Anketa sudaryta remiantis Anglijos laisvalaikio sprendimu tinklalapio (England Leisure Net-Solution, 2011), Amerikos parku ir rekreacijos departamento (American Parks \& Recreation Department, 2005) bei Oregono parku ir rekreacijos departamento (Oregon Parks and Recreation Department, 2007) tyrimu duomenimis. Gauti duomenys suvesti ir apdoroti MS Excel programa, taikant aprašomosios statistikos metodą.

\section{TYRIMO REZULTATAI}

Siekiant nustatyti veiksnius, lemiančius kauniečių pasirinkimą laisvalaikiu sportuoti gryname ore naudojant lauko treniruoklius, buvo atliktas tyrimas, kurio rezultatai parodé, kad didžioji dalis apklaustų Kauno gyventoju ( $n=284 ; 77$ proc.) aktyvų laisvalaiki lauko treniruoklių aikštelèse vertina teigiamai ir mano, kad toks fizinis aktyvumas yra patraukli laisvalaikio forma. Taip pat nustatyta, kad daugiau nei pusè respondentu ( $n=218 ; 59$ proc.) laisvalaikiu renkasi sportavimą lauko treniruokliu aikštelèje, todèl galima daryti prielaidą, kad Kauno gyventojai laisvalaikiu gana aktyviai naudojasi lauko treniruokliais.

Tiriant veiksnius, turinčius ịtakos lauko treniruoklių pasirinkimui laisvalaikiu, paaiškèjo (1 pav.), kad kauniečių pasirinkimą sportuoti gryname ore lauko treniruoklių aikštelèse daugiausia lemia nemokama paslauga $(\mathrm{n}=114 ; 31$ proc.), rami aplinka $(\mathrm{n}=84 ; 23$ proc.), lauko treniruoklių ivairovè $(\mathrm{n}=74 ; 20$ proc.) ir patogus lauko treniruoklių aikštelių geografinis išsidèstymas $(\mathrm{n}=59$; 16 proc.).

Analizuojant naudingumo faktorius, lemiančius lauko treniruoklių pasirinkimą laisvalaikiu nustatyta (2 pav.), kad Kauno gyventojai didžiausią naudą patiria, galėdami aktyviai leisti laisvalaiki gamtoje, sportuodami lauko treniruoklių aikštelèse (atsakymų vidurkis 3,9). Respondentai taip pat sutinka, kad sportavimas lauko treniruoklių aikštelëje padeda gerinti miego kokybę $(3,5)$, rasti 
bendraminčių, draugu $(3,4)$, ugdyti valią ir ištvermę $(3,3)$, atgauti energiją ir sumažinti ịtampą $(3,3)$, pagerinti savijautą $(3,2)$, atsipalaiduoti po darbo dienos $(3,1)$, suteikia galimybę daugiau laiko praleisti su draugais, šeima $(3,1)$, padeda geriau pajusti ir pažinti savo kūną $(3,0)$, tobulinti kūno formas $(3,0)$, be to, patrauklu tai, kad paslauga ištisus metus teikiama nemokamai $(3,1)$.

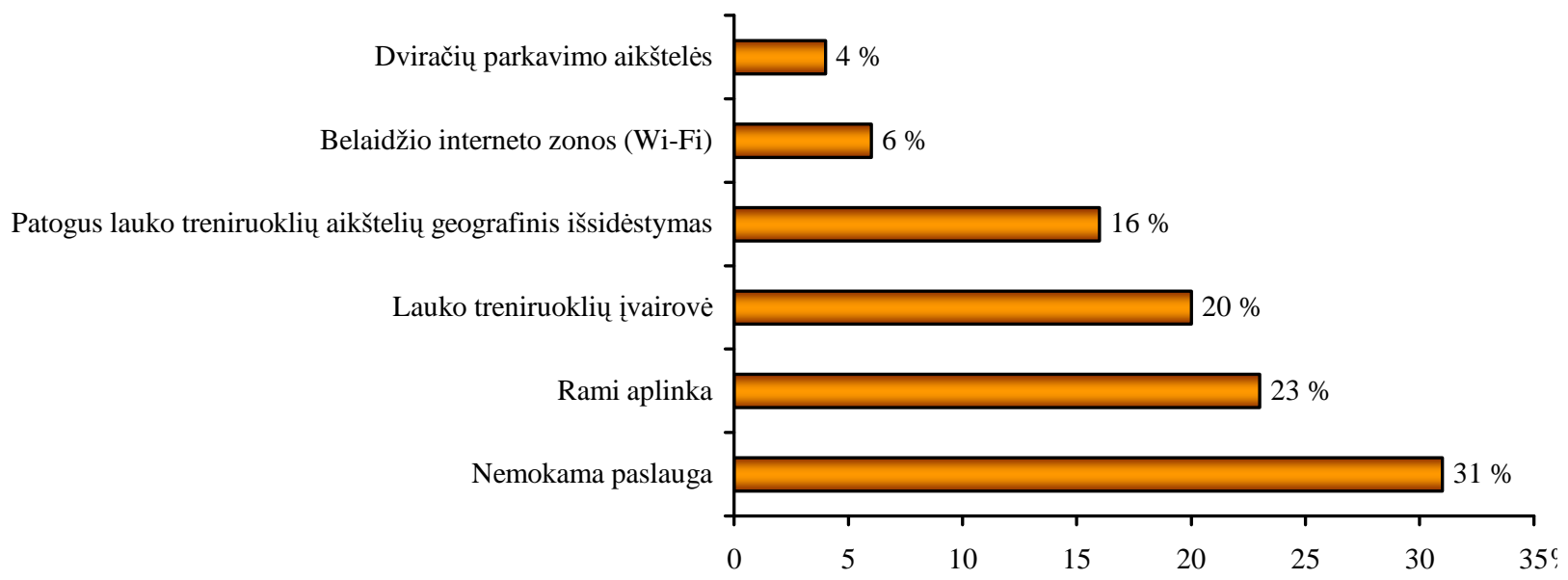

1 pav. Veiksnių, turinčių itakos lauko treniruoklių pasirinkimui laisvalaikiu, skirstinys (proc.)

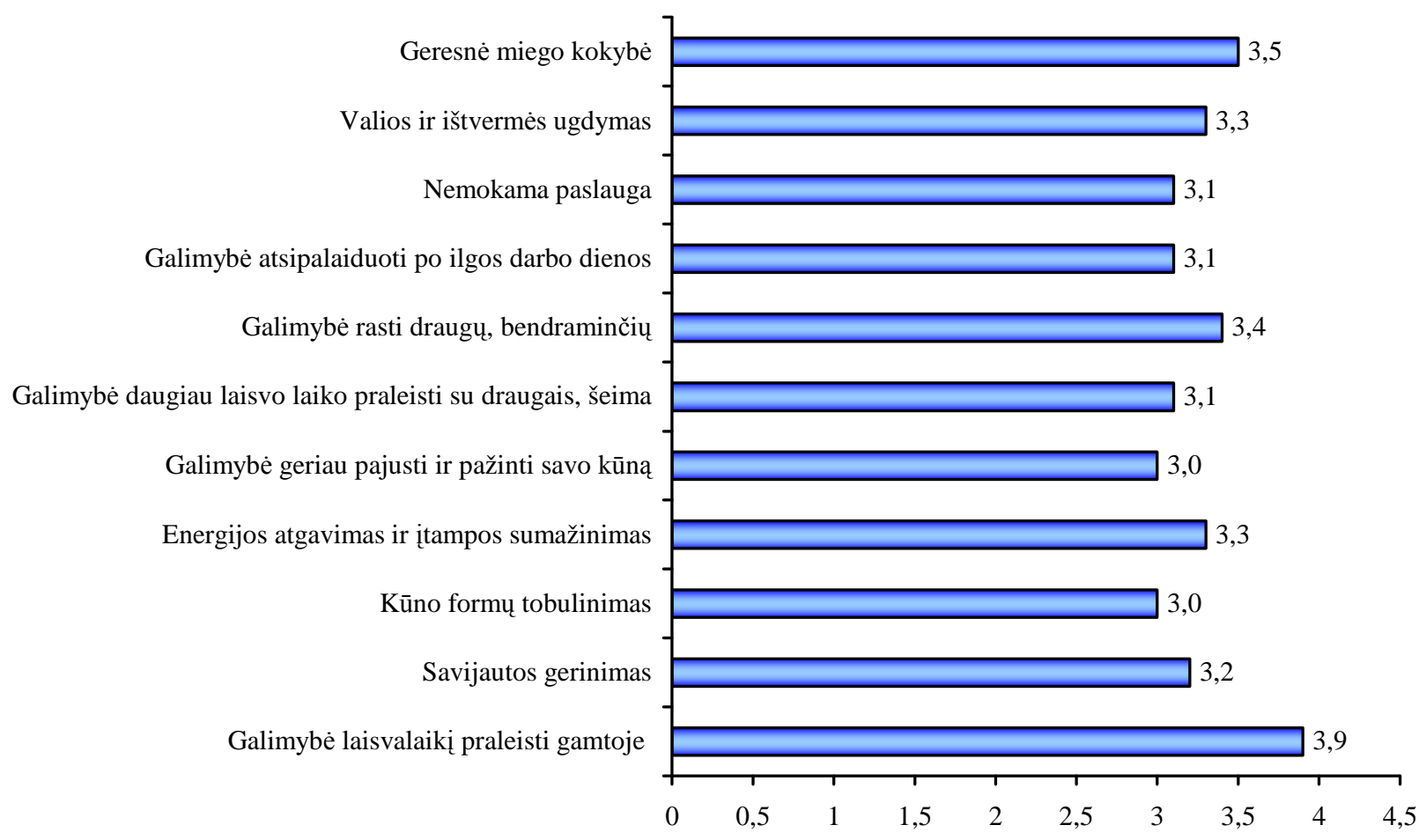

2 pav. Sportavimo lauko treniruoklių aukštelëje naudingumo faktorių skirstinys

Ivertinus Kauno miesto gyventojų nuomonès tyrimo rezultatus galima daryti prielaidac, kad sportavimas gryname ore lauko treniruoklių aikštelèse yra tinkama ir naudinga laisvalaikio leidimo forma. Galima teigti, kad veiksniai, turintys didžiausios ittakos kauniečiu pasirinkimui sportuoti gryname ore, yra nemokama paslauga, rami aplinka, lauko treniruoklių ívairovė ir patogus geografinis lauko treniruoklių aikštelių išsidèstymas. 
Išanalizavus lauko treniruoklių naudingumo faktorius galima teigti, kad didžiausia nauda, kurią Kauno miesto gyventojai patiria leisdami laisvalaiki lauko treniruokliu aikštelèse, yra galimybè aktyviai praleisti laisvalaiki gamtoje. Tyrimo rezultatai parodé, kad lauko treniruokliai yra tinkama priemonè žmonių fizinei, socialinei, psichologinei ir emocinei būsenai gerinti. Todèl galima daryti prielaidą, kad aktyvus laisvalaikio leidimas lauko treniruoklių aikštelèse gyventojams yra naudingas, nes padeda gerinti gyvenimo kokybę.

\section{IŠVADOS}

1. Pastaruoju metu vis daugiau Kauno miesto parkų pertvarkoma i laisvalaikio zonas, kuriose visuomenė turi galimybę naudotis įvairiomis aktyvaus laisvalaikio paslaugomis, tarp jų - ir galimybę sportuoti gryname ore lauko treniruokliu aikštelèse. Tokių aikštelių plètra padeda mažinti pasyvių žmonių skaičių, plèsti socialini vartotojų akiratị, skatina racionalų parkų išteklių naudojimą, suteikia žmonėms puikią galimybę aktyviai praleisti laisvalaiki gamtoje.

2. Nustatyta, kad veiksniai, turintys didžiausios įtakos kauniečiu pasirinkimui laisvalaikiu sportuoti lauko treniruoklių aikštelèse, yra nemokama paslauga, rami aplinka, lauko treniruoklių ivvairovè ir patogus lauko treniruoklių aikšteliu geografinis išsidèstymas. Ši pasirinkimą lemia ir tokie naudingumo faktoriai, kaip galimybe praleisti laisvalaiki gryname ore, pagerinti miego kokybę, rasti draugu ir bendraminčiu, ugdyti valią ir ištvermę, atgauti energiją ir sumažinti itampą, tobulinti kūno formas.

\section{LITERATŪRA}

1. Bell, S., Tyrvainen, L., Sievanen, T., Probstl, U., Simpson, M. (2007). Outdoor recreation and nature tourism: A European perspective. Living Reviews in Landscape Research, 2, 5-38. Prieiga per internetą: http://landscaperesearch.livingreviews.org/Articles/lrlr-2007-2/download/lrlr-20072Color.pdf [žiūrèta 2013-02-27].

2. Deborah, A. C., Thomas, L. M, Sehgal, A., Williamson, S., Golinelli D., Lurie, N. (2007). Contribution of public parks to physical activity. American Journal of Public Health, vol. 97, p. 509-514.

3. Frumkin, H. (2003). Healthy places: Exploring the evidence. American Journal of Public Health, 9, 1451-1456.

4. Godbey, G., Mowen, A. (2010). The Benefits of Physical Activity. Provided by Park and Recreation Services. The Scientific Evidence. National Recreation and Park Association. Prieiga per internetą: http://www.nrpa.org/uploadedFiles/nrpa.org/Publications_and_Research/Research/Papers/GodbeyMowen-Research-Paper.pdf [žiūrèta 2013-02-05].

5. Jankauskienè, R. (2008). Lietuvos gyventojų fizinio aktyvumo skatinimo strategija: kūno kultūra ar kūno kultas? Medicina (Kaunas), 44 (5), 346-355. Prieiga per internetą: http://medicina.kmu.lt/0805/0805021.pdf [žiūrèta 2013-02-19].

6. Horká, H., Hromádka, Z. (2010). Active Leisure for health in context of environmental care. In E. Řehulka (ed.) School And Health 21. Health Education: International Experiences. Brno: Masarykova univerzita, p. 275-289.

Prieiga per internetą: http://www.ped.muni.cz/ z21/knihy/2010/35/35/texty/eng/horka_hromadka.pdf [žiürèta 2013-02-21].

7. Leisure-net solution: Outdoor Fitness Classes Report. (2012). Fitness Industry Association. (England). Prieiga per internetą: http://www.liw.co.uk/files/outdoor_fitness_research_report_finalversion.pdf [žiūrèta 2013-03-05]. 
8. Peters, K. (2010). Being together in urban parks: Connecting public space, leisure, and Diversity. Leisure Sciences: An Interdisciplinary Journal, 32 (5), 418-433.

9. Pigram, J. J., Jenkins, J. M. (2006). Outdoor Recreation Management. London: Routledge Press.

10. Rosenberger, R. S., Bergerson, R. T., Kline, J. D. (2009). Macro-linkages between health and outdoor recreation: The role of parks and recreation providers. Journal of Park and Recreation Administration, 27 (3), 8-20.

11. Tekin, A. (2004). Sport tourism - an animation perspective. Journal of Sport and Tourism, 9 (4), 317-322.

12. Vitkienè, E. (2008). Rekreacija (Rekreacijos marketingo tyrimai): monografija. Klaipèda: Klaipėdos universiteto leidykla.

13. Walker, C. (2004). The public value of urban parks. In: Beyond Recreation: A Broader View of Urban Parks. Washington, DC: The Urban Institute. 


\title{
FACTORS HAVING INFLUENCE ON THE KAUNAS CITY RESIDENTS CHOICE TO HAVE ACTIVE LEISURE TIME IN OUTDOOR FITNESS SITES
}

\author{
Giedrè Gudaitytė, Irena Valantinè \\ Lithuanian Sports University, Kaunas, Lithuania
}

\begin{abstract}
Research results analysed and systematized in the paper identified factors that influenced the choice of fitness outdoor equipment in Kaunas city. Factors influencing the choice of fitness outdoor equipment were analysed in order to identify the measures that stimulate people to spend active leisure time in outdoor fitness sites. The latest scientific research results systematised (Horká, Hromádka, 2010; Bell et al., 2007; Tekin, 2004; Deborah et al., 2007; Rosenberger, Bergerson, Kline, 2009); Godbey, Mowen, 2010; Walker, 2004; Pigram, Jenkins, 2006) allow formulating new research topics for the promotion of active outdoor fitness.

The object of the survey was the factors that influence the choice of outdoor fitness equipment at leisure time.

The aim of the survey was to identify the factors that influence the choice of Kaunas City residents to spend leisure time at outdoor fitness sites.

Research objectives:

1. To investigate the possibilities of outdoor fitness equipment use.

2. To identify the factors that encourage Kaunas city residents to exercise in the fresh air with outdoor fitness equipment.

Research methods applied were analysis of the scientific literature, questionnaire survey, and descriptive statistics.

Research results. The research revealed that sport in the open air with outdoor fitness equipment is an attractive form for active leisure time. It is believed that one of the main factors of the choice that promotes to choose outdoor fitness equipment is a free service, quiet environment, a variety of outdoor fitness equipment and a favourable geographical location of the site. Performance factors as opportunity to spend active leisure in nature, better quality of sleep, finding new friends, training of will and endurance, extension of the energy, removing stress and body shape improvement also determine the choice to have sport in the fresh air.
\end{abstract}

Keywords: active leisure, outdoor fitness equipment, city parks. 


\title{
ФАКТОРЫ, ОБУСЛАВЛИВАЮЩИЕ ВЫБОР ЖИТЕЛЕЙ КАУНАСА АКТИВНО ПРОВОДИТЬ ДОСУГ НА ОТКРЫТЫХ ТРЕНАЖЕРНЫХ ПЛОЩАДКАХ
}

\author{
Гедре Гудайтите, Ирена Валантине \\ Литовский университет спорта, Каунас, Литва
}

\section{PЕЗЮМЕ}

В статье анализируються и систематизируються результаты исследования факторов, влияющих на выбор жителей Каунаса проводить свой досуг на открытых тренажерных площадках. Факторы, влияющие на выбор тренажеров, анализируються с целью выявить меры поощрения общественности для активного проведения свободного времени на открытых тренажерных площадках. Систематизированные новейшие исследования ученых (Horká, Hromádka, 2010; Bellet al., 2007; Tekin, 2004; Deborah et al., 2007; Rosenberger, Bergerson, Kline, 2009; Godbey, Mowen, 2010; Walker, 2004; Pigram, Jenkins, 2006) позволяют определить новые темы для исследования поощрения активного проведения досуга.

Объект исследования - факторы, влияющие на выбор тренажеров для проведения досуга на открытых спортивных площадках.

Цель исследования - определить факторы, влияющие на выбор жителей Каунаса проводить досуг на открытых тренажерных площадках.

\section{Задачи исследования:}

1. Определить возможности использования тренажеров для проведения досуга на открытых спортивных площадках.

2. Выявить факторы, определяющие выбор жителей Каунаса заниматься спортом на свежем воздухе на открытых тренажерных площадках.

Методы исследования: анализ научной литературы, анкетирование, описательная статистика.

Результаты исследования. Исследование показало, что физическая деятельность на свежем воздухе на открытых тренажерных площадках является привлекательной формой активного отдыха. Считается, что одним из основных факторов, влияющих на выбор проведения своего досуга на открытых тренажерных площадках, это бесплатная услуга, спокойное место, разнообразие тренажеров и удобное географическое расположение тренажерных площадок. Выбор жителей Каунаса упражняться на открытых тренажерных площадках определяют и такие факторы полезности, как возможность активно провести свой досуг на свежем воздухе, улучшить качество сна, найти друзей и единомышленников, развивать волю и выносливость, восстановить энергию и снять стресс, улучшить форму тела.

Ключевые слова: активный отдых, тренажеры для занятий на открытых площадках, городские парки. 